\title{
Appearance of a stress-response protein, phage-shock protein A, in Escherichia coli exposed to hydrophobic organic solvents
}

\author{
Hideki Kobayashi, Mami Yamamoto and Rikizo Aono
}

Author for correspondence: Rikizo Aono. Fax: +81 459245819.

e-mail: raono@bio.titech.ac.jp

Department of

Bioengineering, Faculty of

Bioscience and

Biotechnology, Tokyo

Institute of Technology,

Nagatsuta 4259, Midori-ku,

Yokohama, 226, Japan

\begin{abstract}
A $28 \mathrm{kDa}$ protein associated with the inner membrane was induced strongly in Escherichia coli K-12 cells grown in the presence of a hydrophobic organic solvent, $\mathrm{n}$-hexane or cyclooctane. These organic solvents suppressed the growth (growth rate and yield) of $E$. coli. A partial amino acid sequence showed that this protein was the phage-shock protein PspA. PspA is known to be induced in $E$. coli cells under extreme stress conditions. The results suggest that $E$. coli cells are subject to strong stress in the presence of organic solvents. Introduction of a multi-copy plasmid vector carrying the psp operon into $E$. coli improved the survival frequency of cells exposed suddenly to $n$-hexane but not the growth rate of cells growing in the presence of $n$-hexane.
\end{abstract}

Keywords: Escherichia coli, organic solvent, phage shock protein A, psp operon

\section{INTRODUCTION}

In recent years, there has been increasing interest in culturing micro-organisms in two-phase liquid systems composed of an organic solvent and aqueous medium. This approach may provide a convenient means of bioconversion of hydrophobic organic compounds (de Smet et al., 1983; Harbron et al., 1986; Favre-Bulle et al., 1991; Van Sonsbeck et al., 1993; Aono et al., 1994a ; Doukyu \& Aono, 1997).

In the case of micro-organisms, the toxicity of an organic solvent is correlated inversely with $\log P_{\text {ow }}$, when examined on the basis of microbial growth on an agar medium overlaid with organic solvent (Inoue \& Horikoshi, 1989). Here, $\log P_{\text {ow }}$ is defined as the common logarithm of the partition coefficient $\left(P_{\text {ow }}\right)$ of the organic solvent between n-octanol and water layers (Leo, 1993). Each bacterium has its own intrinsic tolerance level for organic solvents. This level is determined genetically although it is also affected by environmental factors (Aono et al., 1991, 1994c, d; Nakajima et al., 1995a, b; Asako et al., 1997). The tolerance level of each microorganism is represented by two terms : the index solvent and the index value. The index solvent is the most toxic organic solvent among those that can be tolerated by the organism. The index value is the $\log P_{\text {ow }}$ value of the

Abbreviations: PSP, phage shock protein; $P_{\text {ow, }}$ partition coefficient. index solvent. Each bacterium can grow on agar medium overlaid with any one of the organic solvents having a $\log P_{\mathrm{ow}}$ value greater than or equal to the index value (Inoue \& Horikoshi, 1989; Aono et al., 1994b).

This empirical rule derived from observations of microbial growth on agar media implies that each organism would also be able to grow in a two-phase liquid system consisting of a nutrient medium and an organic solvent with $\log P_{\text {ow }}$ greater than the index value. However, under such conditions growth of bacteria is suppressed by organic solvents having $\log P_{\mathrm{ow}}$ values near the index value (Aono et al., 1994b). We found that Escherichia coli grown in the presence of $\mathrm{n}$-hexane $\left(\log P_{\mathrm{ow}} 3.9\right)$ or cyclooctane $\left(\log P_{\text {ow }} 4.5\right)$ became increasingly susceptible to the solvent during the course of cultivation. Microorganisms seem to be subject to strong stress in the presence of such harmful organic solvents.

In this paper we show that a $28 \mathrm{kDa}$ protein appears in the inner membrane of $E$. coli cells growing in the presence of a harmful organic solvent. This protein was identified as phage shock protein $\mathrm{A}$ (PspA), a stressresponse protein (Brissette et al., 1991; Weiner et al., 1991; Kleerebezem \& Tommassen, 1993; Bergler et al., 1994), which is induced in E. coli cells under various conditions including treatment with a water-miscible organic solvent, ethanol. This is the first report to show that hydrophobic water-immiscible organic solvents can trigger the induction of PspA. 


\section{METHODS}

Bacterial strains, phage and plasmids. The n-hexane-tolerant strain E. coli K-12 JA300 ( $\mathrm{F}^{-}$thr leuB6 trpC1117 thi rpsL20 $\left[\mathrm{Str}^{\mathrm{r}}\right]$ hsdS) (Kingsman et al., 1979) was the main strain used in this study. E. coli K-12 LE392 (supE44 supF58 galK2 metB1 trpR55 lacY1) (Murray et al., 1977) and E. coli K-12 JM109 (recA1 endA1 gyrA96 thi hsdR17 supE44 relA1 $\Delta[$ lac

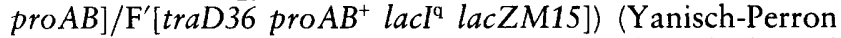
\& Messing, 1985) were used for phage stock and plasmid construction. Kohara's recombinant phage $\lambda 1 \mathrm{C} 2$ (Kohara et al., 1987) was used as a donor of the psp operon. Plasmid pUC119 was used as a cloning vector. The recombinant plasmid ( $p$ PSP3) carrying the $p s p$ operon was constructed in this study.

Culture media. E. coli JA300 was grown at $37^{\circ} \mathrm{C}$ in $\mathrm{LBGMg}$ medium, consisting of $10 \mathrm{~g}$ Bacto Tryptone (Difco), $5 \mathrm{~g}$ Bacto yeast extract (Difco), $10 \mathrm{~g} \mathrm{NaCl}, 1 \mathrm{~g}$ glucose and $10 \mathrm{mmol}$ $\mathrm{MgSO}_{4} \mathrm{I}^{-1}$ (Aono et al., 1991). In some experiments, the organism was also grown in LBG medium (LBGMg medium without $\left.\mathrm{MgSO}_{4}\right)$. When necessary, the media were solidified with $1.5 \%$ (w/v) agar. NZYM medium, consisting of $10 \mathrm{~g} \mathrm{NZ}$ amine (Difco), $5 \mathrm{~g}$ yeast extract (Difco), $5 \mathrm{~g} \mathrm{NaCl}$ and $2 \mathrm{~g}$ $\mathrm{MgSO}_{4} \cdot 7 \mathrm{H}_{2} \mathrm{O}^{-1}$ (Luria \& Burrous, 1957), was used for phage propagation. When necessary, ampicillin $\left(50 \mu \mathrm{g} \mathrm{m}^{-1}\right)$ was added to the media.

Preparation of inner-membrane protein fraction. The organism was grown in LBGMg medium. The cells were harvested by centrifugation $\left(3500 \mathrm{~g}, 10 \mathrm{~min}, 4^{\circ} \mathrm{C}\right)$, washed with cold $10 \mathrm{mM} \mathrm{Na}{ }_{2} \mathrm{HPO}_{4} / \mathrm{NaOH}$ buffer ( $\mathrm{pH} 7 \cdot 0$ ), then suspended in the buffer and broken by sonication in an icewater bath. Unbroken cells were removed by centrifugation $\left(3500 \mathrm{~g}, 10 \mathrm{~min}, 4^{\circ} \mathrm{C}\right)$, the envelope fraction was precipitated by further centrifugation $\left(100000 \mathrm{~g}, 45 \mathrm{~min}, 4^{\circ} \mathrm{C}\right)$, and the pellet was washed once with the cold buffer. This envelope was incubated in the phosphate buffer containing $0.5 \%$ sodium $N$-lauroyl sarcosine (Sarkosyl) for $30 \mathrm{~min}$ at room temperature at a protein concentration of $3 \mathrm{mg} \mathrm{ml}^{-1}$ (Camille et al., 1973). The suspension was centrifuged at $100000 \mathrm{~g}$ for $45 \mathrm{~min}$ at $15^{\circ} \mathrm{C}$. The supernatant was used as the innermembrane protein fraction. The pellet was washed twice with the Sarkosyl buffer and used as the outer-membrane protein fraction.

SDSPAGE of proteins. Samples were dissolved in $1 \%$ SDS, $2.5 \%(\mathrm{v} / \mathrm{v}) \quad \beta$-mercaptoethanol, $20 \%(\mathrm{w} / \mathrm{v})$ sucrose and $16 \mathrm{mM}$ Tris/ $\mathrm{HCl}$ buffer ( $\mathrm{pH} \mathrm{6.8)}$, and heated for $5 \mathrm{~min}$ in a boiling bath. The samples were electrophoresed on a $0.1 \%$ SDS $/ 15 \%(\mathrm{w} / \mathrm{v})$ polyacrylamide gel by the Laemmli method (Laemmli, 1970). After electrophoresis, the protein in the gel was stained with Coomassie brilliant blue R-250.

Protein content. This was measured by the Lowry method.

$\mathrm{N}$-terminal amino acid sequence. This was determined by Edman degradation using an Applied Biosystems protein sequencer 473A.

DNA manipulation. DNA manipulations, including preparation of plasmid DNA, restriction enzyme digestion, ligation, and transformation of $E$. coli, were carried out by standard methods. DNA from recombinant phage $\lambda 1 \mathrm{C} 2$ was isolated by using the QIAGEN Lambda kit with E. coli JM109 as a host.

Materials. The cyclooctane and n-hexane used were of the highest quality available; they were purchased from Wako Pure Chemical Industries. The $\log P_{\text {ow }}$ values of organic solvents were calculated by the addition rule (Leo, 1993) using the $\log P_{\mathrm{ow}}$ calculation software, ClogP version 1.0.3 (Bio Byte Corporation).

\section{RESULTS}

\section{Growth of E. coli JA300 in the presence of harmful organic solvents}

We have previously examined the toxicity of organic solvents by observing microbial colony formation on agar medium overlaid with the organic solvent. For $E$. coli JA300, the index solvent is n-hexane $\left(\log P_{\text {ow }} 3 \cdot 9\right)$ (Aono et al., 1991). When an organic solvent with a log $P_{\text {ow }}$ value much greater than the index value, such as dodecane $\left(\log P_{\text {ow }} 7 \cdot 0\right)$, decane $\left(\log P_{\text {ow }} 6 \cdot 0\right)$, or isooctane $\left(\log P_{\text {ow }} 4 \cdot 8\right)$, was added suddenly to JA300 cells growing in LBGMg medium, growth was not inhibited for at least $20 \mathrm{~h}$, as indicated by monitoring the turbidity and the number of viable cells. Fig. 1 shows the growth of JA300 after addition of isooctane. There was no evidence of a phase of adaptation to these organic solvents added suddenly.

In contrast, addition of n-hexane interrupted growth severely and caused a rapid decrease in the number of

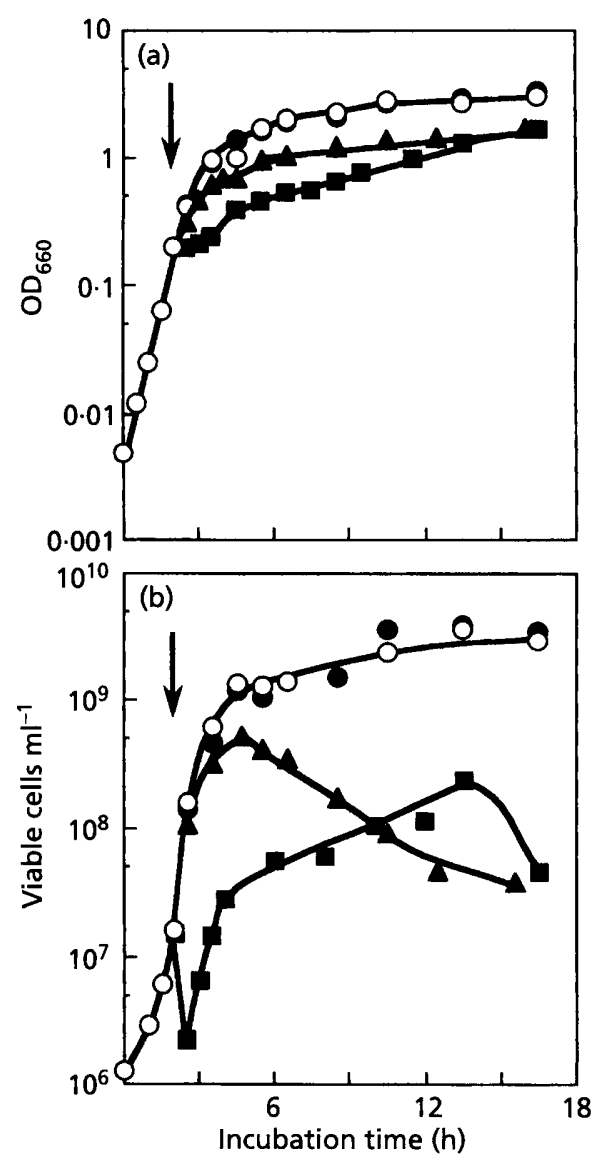

Fig. 1. Effects of organic solvents with $\log P_{\text {ow }}$ near the index value on growth of $E$. coli JA300. The strain was grown in LBGMg medium aerobically at $37^{\circ} \mathrm{C}$. To the culture $\left(O D_{660} 0.1\right)$, a $10 \%$ volume of isooctane ( $\left.\log P_{\text {ow }} 4.8 ; 0\right)$, cyclooctane (log $\left.P_{\text {ow }} 4.5 ; \boldsymbol{A}\right)$ or $n$-hexane $\left(\log P_{\text {ow }} 3.9 ; \square\right)$ was added at the time indicated by the arrow. Growth was followed by measuring culture turbidity at $660 \mathrm{~nm}$ (a) and viable cells (b). $O$, No organic solvent added. Graphs show typical results obtained from three independent experiments. 
viable cells, as described previously (Aono et al., 1994b). Immediately after the addition, the colony-forming ability of most cells was lost (Fig. 1). The cell survival frequency was $10-20 \%$ at $0.5 \mathrm{~h}$ after the addition of $\mathrm{n}$ hexane. The survivors grew for $2 \mathrm{~h}$ in LBGMg medium overlaid with $\mathrm{n}$-hexane at a growth rate (doubling time $25 \mathrm{~min}$ ) similar to that found in the absence of $\mathrm{n}$-hexane. Thereafter, the growth rate was retarded (doubling time $3 \mathrm{~h}$ ). The culture turbidity increased constantly although the rate of increase was suppressed by $n$-hexane. The frequency of survivors found after the addition of $n$ hexane was sufficiently high to conclude that the survivors were not n-hexane-tolerant mutants which might appear at a low frequency. It is obvious that JA300 cells grew via physiological adaptation to an environment 'polluted' with n-hexane.

JA300 continued to grow for a while after the addition of cyclooctane $\left(\log P_{\text {ow }} 4.5\right)$ or diphenyl ether $\left(\log P_{\text {ow }}\right.$ $4 \cdot 2$ ), although the growth rate was lowered slightly by each organic solvent. Fig. 1 shows the growth profile after the addition of cyclooctane. The number of viable cells began to decrease gradually $3 \mathrm{~h}$ after the addition of cyclooctane although the turbidity continued to increase at a rate lowered slightly by isooctane. These results indicated that an organic solvent having a $\log P_{\mathrm{ow}}$ value which was 0.6 greater than the index value was sufficiently harmful to suppress the growth of JA300 in the late exponential phase of growth.

\section{Appearance of a $28 \mathrm{kDa}$ inner-membrane-associated protein in E. coli cells growing in the presence of organic solvents}

We assumed that some alteration adapted to the environment containing organic solvents was caused in the membrane. Envelope fractions were prepared from E. coli JA300 grown in the presence of the organic solvents for $2 \mathrm{~h}$. The envelope proteins were fractionated by solubilization with Sarkosyl and examined by SDSPAGE (Fig. 2). A protein band corresponding to a molecular mass of $28 \mathrm{kDa}$ was found in the Sarkosylsoluble protein fraction prepared from the cells grown in the presence of $n$-hexane. This protein band was not found in the samples prepared from the cells growing without n-hexane. The Sarkosyl-soluble protein fraction is mainly inner-membrane protein (Camille et al., 1973). There was no difference in Sarkosyl-insoluble envelope protein fractions, mainly containing outer-membrane proteins. Thus, the $28 \mathrm{kDa}$ protein was assumed to be derived from the inner membrane, although the cytoplasmic protein was not examined.

E. coli JA300 was grown in medium overlaid with cyclooctane to observe whether the $28 \mathrm{kDa}$ protein would appear after prolonged incubation in the presence of this solvent. Growth in the presence of organic solvent has been shown to be dependent on the culture conditions, such as nutrients, concentrations of alkaline earth ions and air supply (Aono et al., 1994b; Doukyu \& Aono, 1997; Noguchi et al., 1997). Fig. 3(a) shows a (a)

(b)

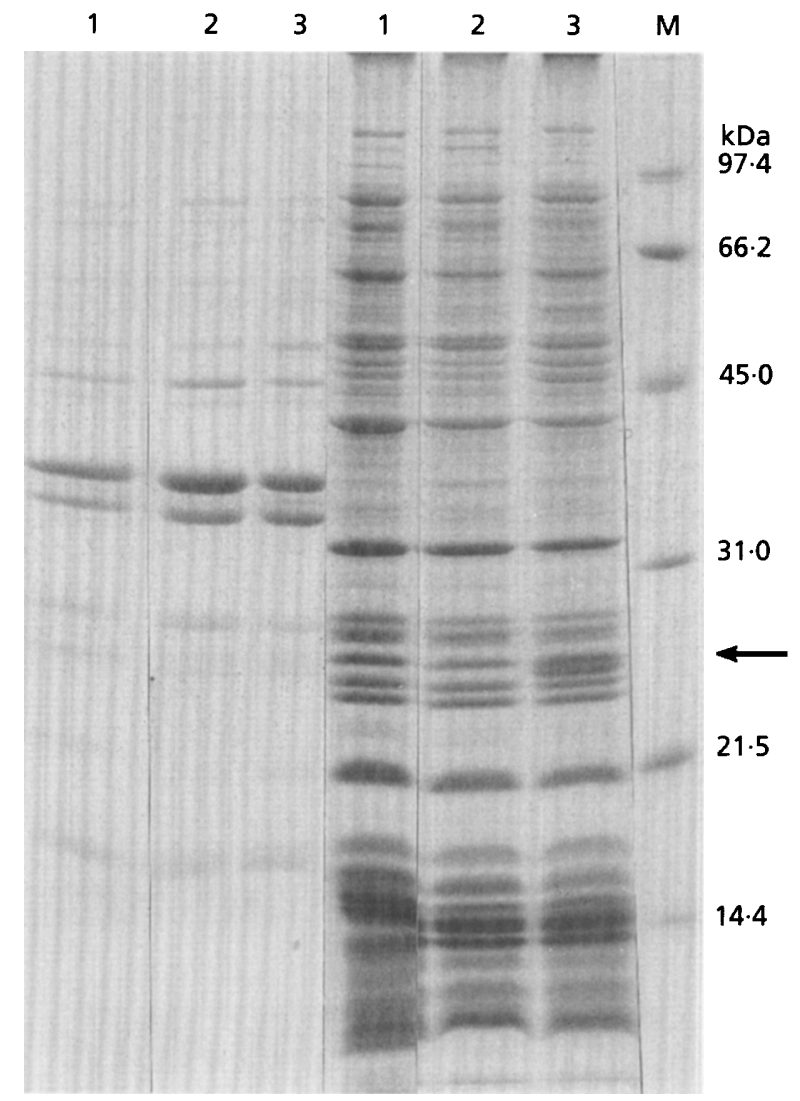

Fig. 2. Appearance of a $28 \mathrm{kDa}$ protein in E. coli JA300 cells exposed to organic solvent. JA300 was grown in the presence of organic solvent as shown in Fig. 1. The envelope fraction was prepared from the cells recovered $2 \mathrm{~h}$ after the addition of organic solvent. The envelope fraction, containing $30 \mu \mathrm{g}$ protein, was extracted with $0.5 \%$ Sarkosyl at room temperature. Sarkosyl-insoluble (a) or -soluble (b) protein was electrophoresed on an SDS-15\% (w/v) polyacrylamide gel. Protein was stained with Coomassie brilliant blue R-250. Lanes: $M$, molecular mass markers; 1 , without organic solvent; 2 , cyclooctane; $3, \mathrm{n}$-hexane. The arrow indicates the $28 \mathrm{kDa}$ protein.

typical growth curve. The cells grew to $2 \times 10^{9} \mathrm{ml}^{-1}$ at $7 \mathrm{~h}$. Thereafter, the number of viable cells decreased gradually and had fallen to $5 \times 10^{8} \mathrm{ml}^{-1}$ at $16 \mathrm{~h}$. Innermembrane protein fractions prepared from the cells were analysed by SDS-PAGE (Fig. 3b). A significant amount of the $28 \mathrm{kDa}$ protein appeared in the inner membrane of the cells grown in the presence of cyclooctane after $6 \mathrm{~h}$. At this time, the growth was retarded by cyclooctane. This protein did not appear within $16 \mathrm{~h}$ when the organism was grown without organic solvent (Fig. 3c).

The $28 \mathrm{kDa}$ protein was induced in the cells when growth was retarded by cyclooctane (Fig. $3 \mathrm{a}, \mathrm{b}$ ). This was the case also for its induction in the presence of $n$ hexane. It is likely that this protein appeared in the inner membrane upon disturbance of membrane structure by 
(a)
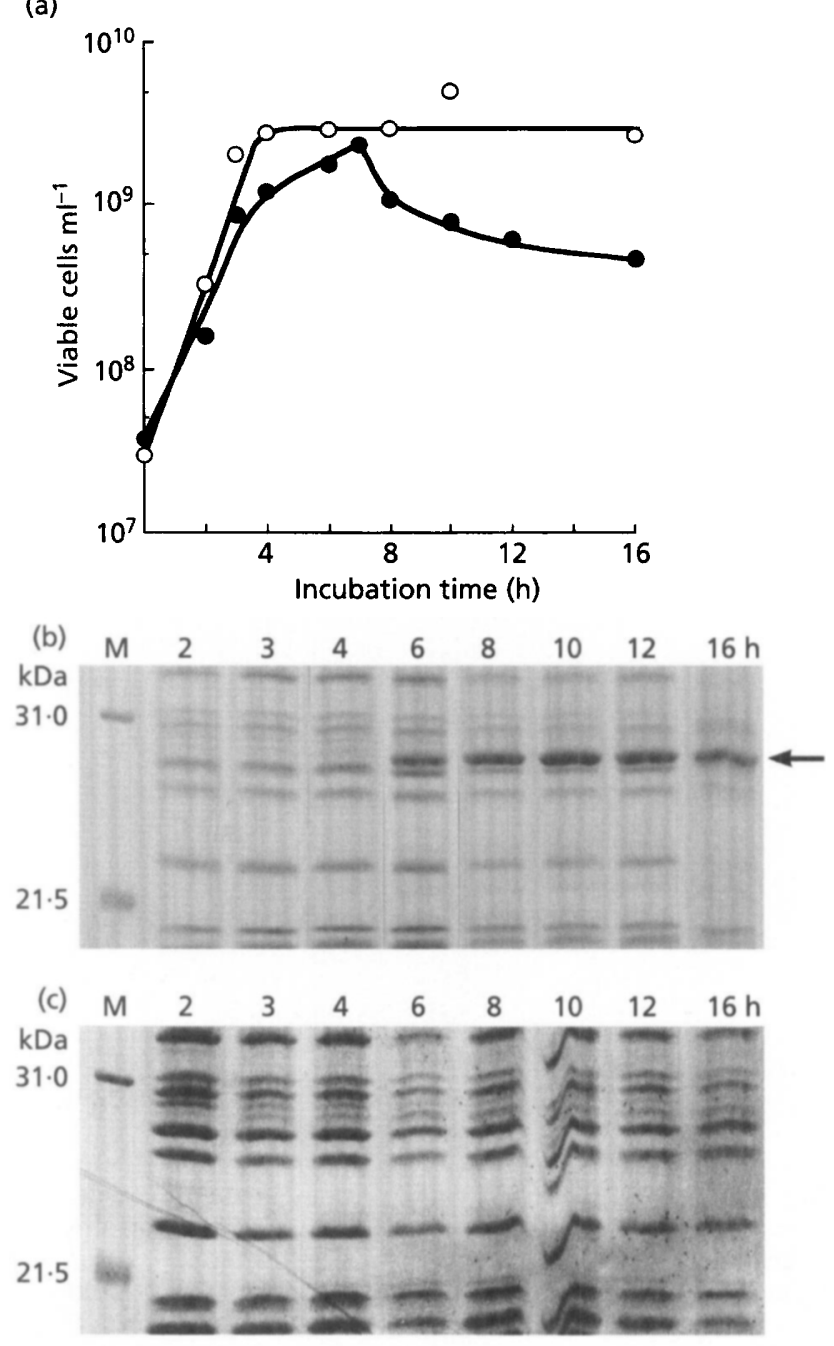

Fig. 3. Appearance of PspA in E. coli $J A 300$ growing in the presence of cyclooctane. JA300 was grown in LBGMg medium overlaid with $10 \%(\mathrm{v} / \mathrm{v})$ cyclooctane $(O)$ or without added solvent (O). The number of viable cells in the medium layer was periodically examined (a). The cells were harvested from the culture with cyclooctane (b) or without added solvent (c) at the times indicated at the top of each gel. Sarkosyl-soluble protein obtained from the whole-envelope fraction, containing $30 \mu \mathrm{g}$ protein, was electrophoresed on an SDS-polyacrylamide gel. Protein was stained with Coomassie brilliant blue R-250. The $28 \mathrm{kDa}$ protein is indicated by the arrow. M, molecular mass markers.

the organic solvents. The protein remained in the inner membrane stably for a long period.

\section{Identification of the $28 \mathrm{kDa}$ inner-membrane protein as PspA}

E. coli JA300 was grown in medium overlaid with a $10 \%$ volume of cyclooctane for $20 \mathrm{~h}$. The Sarkosylsoluble membrane-protein fraction obtained from the cells was separated by SDS-PAGE. The $28 \mathrm{kDa}$ protein was recovered from the gel, and the $19 \mathrm{~N}$-terminal amino acid residues were sequenced. The sequence was
$\mathrm{H}_{2} \mathrm{~N}$-A/GIFXXFADIVNANINALLE-. The N-terminal amino acid was Ala or Gly. The fourth and fifth residues were not clearly identified. This determined sequence was consistent with the sequence, $\mathrm{H}_{2} \mathrm{~N}-\mathrm{MGIFSRFAD}$ IVNANINALLE-, reported for PspA (Brissette et al., 1991). The N-terminal Met residue was not found in the $28 \mathrm{kDa}$ protein recovered from strain JA300. PspA is a $28 \mathrm{kDa}$ peripheral inner-membrane protein of $E$. coli, inducible by various treatments that exert stress. A portion of PspA is present in the cytoplasmic protein fraction. PspA and the $28 \mathrm{kDa}$ protein induced in the presence of organic solvents are identical to each other in location, molecular mass and $\mathrm{N}$-terminal amino acid sequence. Thus, the $28 \mathrm{kDa}$ protein was identified as PspA.

\section{Construction of plasmid pPSP3 carrying the psp operon}

Kohara's recombinant phage $\lambda 1 \mathrm{C} 2$ contains the $p s p$ operon, which includes the pspA-E genes (Kohara et al., 1987; Brissette et al., 1991). DNA from this phage was cleaved by EcoRI. A $4.5 \mathrm{~kb} E c o$ RI fragment containing the $p s p$ operon was inserted into an EcoRI site of vector plasmid pUC119. From the resulting recombinant plasmid (pPSP1), a $2.7 \mathrm{~kb} \mathrm{BglII-EcoRI} \mathrm{fragment} \mathrm{was} \mathrm{sub-}$ cloned into pUC119. This fragment carries $p s p A-E$ but not $p s p F$ (Bergler et al., 1994). Genes $p s p A-E$ constitute one of the two divergent transcription units of the $p s p$ operon. The recombinant plasmid was designated pPSP3.

\section{Expression of pspA in E. coli JA300(pPSP3)}

PspA is one of the stress response proteins. Expression of the $p s p$ operon depends on $\sigma^{54}$ and IHF (integration host factor), and is regulated positively and negatively by the operon genes (Weiner et al., 1991). In recombinant plasmid pPSP3, the operon is inserted downstream of a lac promoter derived from the vector. The PspF-binding sites were deleted and the IHF-binding site was truncated in the cloned DNA. Therefore, the $\sigma^{54}$-dependent promoter is unlikely to be functional.

We examined whether the $p s p$ operon genes carried on the plasmid were expressed in E. coli JA300(pPSP3) under non-stress conditions (Fig. 4). A $28 \mathrm{kDa}$ protein band corresponding to PspA was found in the innermembrane protein fraction prepared from JA300(pPSP3), indicating that the plasmid-borne PspA was produced in JA300 cells not exposed to organic solvent. The expression of $p s p A$ in JA300 cells did not require addition of a lac inducer, such as IPTG. However, the amount of PspA expressed was less than that found in JA300 cells growing in the presence of $n$ hexane or cyclooctane (Figs 2 and 3). Although pPSP3 contains several psp genes, $p s p A, B, C, D$ and $E$, we did not detect any products of this operon other than PspA in the membrane fraction by protein staining. Nor were such products detected for JA300 cells treated with nhexane or cyclooctane (Figs 2 and 3). 


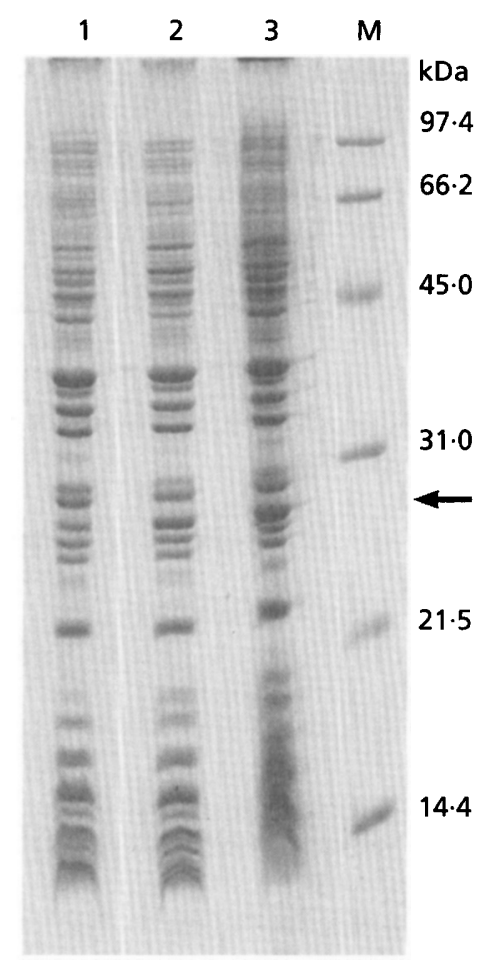

Fig. 4. Expression of PspA in E. coli JA300(pPSP3). JA300 transformed with pUC119 or pPSP3 was grown in LBGMg. Cells in the mid-exponential phase of growth were harvested from the culture. The whole-envelope fraction, containing $30 \mu \mathrm{g}$ protein, was electrophoresed on an SDS-polyacrylamide gel. Protein was stained with Coomassie brilliant blue R-250. The arrow indicates the position of PspA. Lanes: 1, JA300(pUC119); 2, JA300(pPSP3); 3, JA300(pPSP3) treated with $10 \mathrm{mM}$ IPTG for $4 \mathrm{~h}$; $\mathrm{M}$, molecular mass markers.

\section{Effect of the psp operon on the organic solvent tolerance of $E$. coli JA300}

To examine whether the $p s p$ operon was involved in determination of the organic solvent tolerance level of $E$. coli, n-hexane was added to growing JA300(pPSP3) cells (Fig. 5). Alkaline earth cations have been shown to enhance the stability of $E$. coli cells and to elevate organic solvent tolerance levels (Aono et al., 1994b). Therefore, JA300(pPSP3) was grown in medium containing or not containing $10 \mathrm{mM} \mathrm{Mg}{ }^{2+}$. Growth of JA300 and JA300(pPSP3) was inhibited by the addition of $n$-hexane. Growth rates of the survivors were almost identical among the cultures. Therefore, it was concluded that overproduction of PspA did not enhance the growth rate of JA300 in the presence of $n$-hexane.

On the other hand, the cell survival frequency after the addition of $\mathrm{n}$-hexane differed from that observed with $\mathrm{Mg}^{2+}$ supplementation and transformation with the $p s p$ operon. When JA300 cells carrying or not carrying pPSP3 were grown in LBGMg medium, the survival frequencies were similar. However, the survival frequency of JA300 (pPSP3) was higher than that of JA300 when these cells were grown without a high concentration of $\mathrm{Mg}^{2+}$. Overproduction of PspA probably

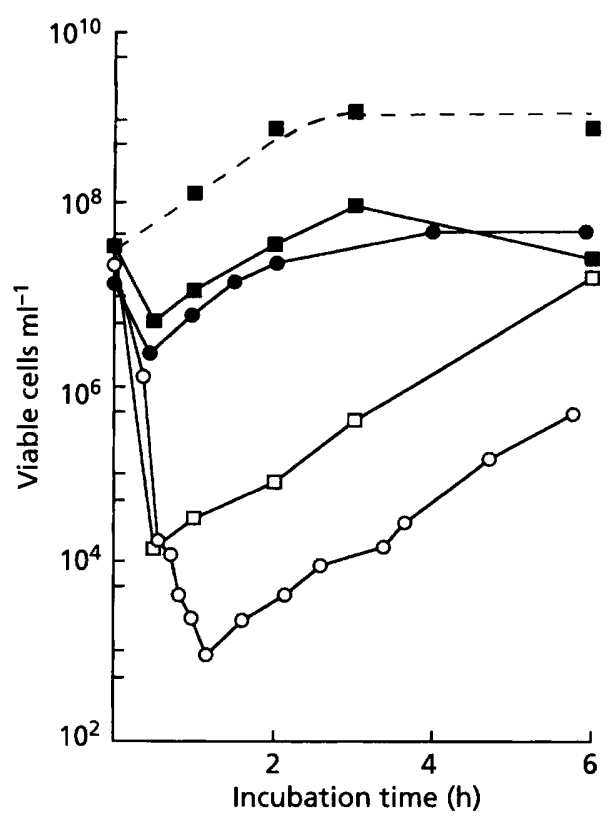

Fig. 5. Effect of the psp operon on growth of $E$. coli $J A 300$ after addition of $n$-hexane. JA300 $(O, \bullet)$ and JA300(pPSP3) ( $\square$, a) were grown in LBG (open symbols) or LBGMg (solid symbols) medium. $n$-Hexane ( $10 \%$ volume) was added to the growing cells at $0 \mathrm{~h}$ (solid lines). JA300(pPSP3) was grown without $n$-hexane as a control (broken lines). The number of viable cells was examined periodically in each culture after the addition of $n$-hexane. The data shown are the mean values for two experiments.

contributes to improvement of the organic solvent tolerance level, as indicated by the enhanced frequency of cell survival after the addition of $\mathrm{n}$-hexane. The $E$. coli inner membrane might be stabilized by PspA, although the effect was much less than that obtained with $10 \mathrm{mM} \mathrm{Mg}^{2+}$. However, it is possible that this stabilization was due to products of genes other than pspA.

\section{DISCUSSION}

PspA was first discovered in E. coli cells infected with filamentous phage (Brissette et al., 1990). pspA is known to be expressed in $E$. coli cells under various stress conditions, such as heat shock at $50{ }^{\circ} \mathrm{C}$, hyper-osmotic shock at $0.75 \mathrm{M} \mathrm{NaCl}, 10 \%$ (v/v) ethanol treatment, inhibition of protein secretion with globomycin, inhibition of fatty acid synthesis with diazaborine, inhibition of ATP synthesis with carbonyl cyanide $m$-chlorophenylhydrazine, or prolonged incubation in the stationary phase of growth (Brissette et al., 1990; Kleerebezem \& Tommassen, 1993; Weiner \& Model, 1994). It is not clear how these stimuli cause induction of the psp operon (Model et al., 1997), but these treatments are all likely to injure the cell membrane.

Hydrophobic organic solvent molecules intercalate into biological membranes (Sikkema et al., 1994). As a result, lipid interaction is weakened and the membrane struc- 
ture is disturbed. Previously, we found that inner and outer membranes of $E$. coli JA300 were often detached from each other when the cells were grown in the presence of $n$-hexane. The periplasmic space was expanded and filled with ribosome-like particles (Aono et al., 1994b). This observation suggests that the inner membrane is damaged structurally upon exposure to $\mathrm{n}$ hexane. We surmised that some adaptive feature might be seen in such damaged membranes.

PspA appeared in the inner membrane of JA300 $2 \mathrm{~h}$ after the addition of $n$-hexane, or after $6 \mathrm{~h}$ in the presence of cyclooctane. At these times, the organism was in the retardation phase of growth due to growth suppression by the organic solvent. It seems that JA300 can grow under stress conditions and the period until appearance of the PspA protein depends on the toxicity of the organic solvent, as estimated on the basis of $\log P_{\text {ow }}$ value. The inner membrane was probably already damaged by the organic solvent at the time when PspA appeared, although its appearance in the cytoplasm was not examined.

PspA overproduced before the shock addition of $n$ hexane failed to improve the growth rate of JA300 $\left(p s p^{+}\right)$in the presence of $\mathrm{n}$-hexane (Fig. 5). However, overproduction of PspA led to improved survival of JA300 growing in LBG medium exposed to the bactericidal action of n-hexane. Recently, it was reported that PspA plays a role in maintenance of the protonmotive force under stress conditions (Kleerebezem $\mathrm{et}$ al., 1996). The organic solvent tolerance is dependent on the respiratory activity (Noguchi et al., 1997). The unusual expansion of the periplasm seems to lower the periplasmic concentration of protons. PspA might be involved in adaptation to an environment polluted with organic solvents by contributing to improvement of the energy production process when the inner membrane has been disturbed by an organic solvent. To confirm this possibility, we need to do further experiments using a $p s p A$-defective mutant and a recombinant plasmid containing only $p s p A$.

\section{ACKNOWLEDGEMENTS}

This work was supported in part by a Grant-in-Aid (Bio Media Program; BMP97-V-1-3-8) from the Ministry of Agriculture, Forestry, and Fisheries of Japan.

\section{REFERENCES}

Aono, R., Aibe, K., Inoue, A. \& Horikoshi, K. (1991). Preparation of organic solvent-tolerant mutants from Escherichia coli K-12. Agric Biol Chem 55, 1935-1938.

Aono, R., Doukyu, N., Kobayashi, H., Nakajima, H. \& Horikoshi, K. (1994a). Oxidative bioconversion of cholesterol by Pseudomonas sp. strain ST-200 in a water-organic solvent two phase system. Appl Environ Microbiol 60, 2518-2523.

Aono, R., Kobayashi, H., Joblin, K. \& Horikoshi, K. (1994b). Effects of organic solvents on growth of Escherichia coli K-12. Biosci Biotech Biochem 58, 2009-2014.

Aono, R., Negishi, T., Aibe, K., Inoue, A. \& Horikoshi, K. (1994c). Mapping of organic solvent tolerance gene ostA in Escherichia coli K-12. Biosci Biotechnol Biochem 58, 1231-1235.
Aono, R., Negishi, T. \& Nakajima, H. (1994d). Cloning of organic solvent tolerance gene ost $A$ that determines $n$-hexane tolerance level in Escherichia coli. Appl Environ Microbiol 60, 4624-4626.

Asako, H., Nakajima, H., Kobayashi, K., Kobayashi, M. \& Aono, R. (1997). Organic solvent tolerance and antibiotic resistance increased by overexpression of marA in Escherichia coli. Appl Environ Microbiol 63, 1428-1433.

Bergler, H., Abraham, D., Aschauer, H. \& Turnowsky, F. (1994). Inhibition of lipid biosynthesis induces the expression of the $p s p A$ gene. Microbiology 140, 1937-1944.

Brissette, J. L., Russel, M., Weiner, L. \& Model, P. (1990). Phage shock protein, a stress protein of Escherichia coli. Proc Natl Acad Sci USA 87, 862-867.

Brissette, J. L., Weiner, L., Ripmaster, T. L. \& Model, P. (1991). Characterization and sequence of the Escherichia coli stressinduced psp operon. J Mol Biol 220, 35-48.

Camille, F., Fletcher, G., Wulft, J. L. \& Earhart, C. F. (1973). Solubilization of cytoplasmic membrane of Escherichia coli by the ionic detergent sodium-laurylsarcosinate. J Bacteriol 115, 717-722.

Doukyu, N. \& Aono, R. (1997). Biodegradation of indole at high concentration by persolvent fermentation with Pseudomonas sp. ST-200. Extremophiles 1, 100-105.

Favre-Bulle, O., Schouten, T., Kingma, J. \& Witholt, B. (1991). Bioconversion of $n$-octane to octanic acid by a recombinant Escherichia coli cultured in a two-liquid phase bioreactor. Bio/Technology 9, 367-371.

Harbron, S., Smith, B. W. \& Lilly, M. D. (1986). Two-liquid phase biocatalysis: epoxidation of 1,7-octadiene by Pseudomonas putida. Enzyme Microb Technol 8, 85-88.

Inoue, A. \& Horikoshi, K. (1989). A Pseudomonas thrives in high concentrations of toluene. Nature 338, 264-265.

Kingsman, A. J., Clarke, L., Mortimer, R. K. \& Carbon, J. (1979). Replication in Saccharomyces cerevisiae of plasmid pBR31 3 carrying DNA from the yeast trpl region. Gene 7, 141-152.

Kleerebezem, M. \& Tommassen, J. (1993). Expression of the $p s p A$ gene stimulates efficient protein export in Escherichia coli. Mol Microbiol 7, 957-965.

Kleerebezem, M., Crielaard, W. \& Tommassen, J. (1996). Involvement of stress protein PspA (phage shock protein A) of Escherichia coli in maintenance of the protonmotive force under stress conditions. EMBO J 15, 162-171.

Kohara, Y., Akiyama, K. \& Isono, K. (1987). The physical map of the whole E. coli chromosome: application of a new strategy for rapid analysis and sorting of a large genomic library. Cell 50, 495-508.

Laemmli, U. K. (1970). Cleavage of structural proteins during the assembly of the head of bacteriophage T4. Nature 227, 680-685. Leo, A. J. (1993). Calculating $\log P_{\text {oct }}$ from structures. Chem Rev 93, 1281-1306.

Luria, S. E. \& Burrous, J. W. (1957). Hybridization between Escherichia coli and Shigella. J Bacteriol 74, 461-476.

Model, P., Jovanovic, G. \& Dworkin, J. (1997). The Escherichia coli phage-shock-protein $(p s p)$ operon. Mol Microbiol 24, 255-261.

Murray, N. E., Brammer, W. J. \& Murray, K. (1977). Lambdoid phages that simplify the recovery of in vitro recombinants. $\mathrm{Mol}$ Gen Genet 150, 53-61.

Nakajima, H., Kobayashi, K., Kobayashi, M., Asako, H. \& Aono, R. (1995a). Overexpression of the robA gene increases organic solvent tolerance and multiple antibiotic and heavy metal ion 
resistance in Escherichia coli. Appl Environ Microbiol 61, 2302-2307.

Nakajima, H., Kobayashi, M., Negishi, T. \& Aono, R. (1995b). soxRS gene increased the level of organic tolerance in Escherichia coli. Biosci Biotechnol Biochem 59, 1323-1325.

Noguchi, K., Nakajima, H. \& Aono, R. (1997). Effects of oxygen and nitrate on growth of Escherichia coli and Pseudomonas aeruginosa in the presence of organic solvents. Extremophiles 1, 193-198.

Sikkema, J., de Bont, J. A. M. \& Poolman, B. (1994). Interactions of cyclic hydrocarbons with biological membranes. J Biol Chem 269, 8022-8028.

de Smet, M.-J., Kingma, J., Wynberg, H. \& Witholt, B. (1983). Pseudomonas oleovorans as a tool in bioconversions of hydrocarbons: growth, morphology and conversion characteristics in different two-phase systems. Enzyme Microb Technol 5, 352-360.
Van Sonsbeck, H. M., Beeftink, H. H. \& Tramper, T. (1993). Twoliquid-phase bioreactors. Enzyme Microb Technol 15, 722-729.

Weiner, L. \& Model, P. (1994). Role of Escherichia coli stressresponse operon in stationary-phase survival. Proc Natl Acad Sci USA 91, 2191-2195.

Weiner, L., Brissette, J. L. \& Model, P. (1991). Stress-induced expression of the Escherichia coli phage shock protein operon is dependent on $\sigma^{54}$ and modulated by positive and negative feedback mechanisms. Genes Dev 5, 1912-1923.

Yanisch-Perron, C. \& Messing, J. (1985). Improved M13 phage cloning vectors and host strains: nucleotide sequences of M13mp18 and pUC19 vectors. Gene 33, 103-119.

Received 3 June 1997; revised 22 September 1997; accepted 1 October 1997. 